\title{
Characterization of Rubber Shell Liquid Smoke at Various Pyrolysis Temperatures and the Application to Latex Coagulant
}

\author{
Yuni Adiningsih ${ }^{1 *}$ Fauziati $^{1}$ Ageng Priatni ${ }^{1}$ Haspiadi $^{1}$ \\ ${ }^{1}$ Institute of Research and Standardization Industry Samarinda \\ Jl. MT. Haryono/Banggeris No. 1 Samarinda, East Kalimantan, Indonesia \\ "Corresponding author. Email: y_adiningsih@yahoo.co.id
}

\begin{abstract}
Rubber commodities in East Kalimantan have a significant growth area. From 2008 to 2017, the rubber plantation area's growth averaged $3.79 \%$, with rubber production growth up to $4.88 \%$ per year. In addition to producing rubber latex, which is the main product of rubber trees, it also produced many rubber shells. With the vast achievement of rubber plantation area in East Kalimantan, the rubber shells production will increase as well so that it has the potential to become untapped waste. The test results of the chemical content of rubber shells taken from smallholder plantations in the Marang Kayu area contain high halo cellulose and alpha-cellulose levels, about $76.7 \%$ and 44.267 so that it has the potential to be processed into liquid smoke. Research has been carried out on rubber shell liquid smokes manufacture using a pyrolysis process with various temperatures of $250-300^{\circ} \mathrm{C}, 300-350^{\circ} \mathrm{C}, 350-400^{\circ} \mathrm{C}$ and $400-$ $425^{\circ} \mathrm{C}$. The highest liquid smoke rendement is at pyrolysis temperatures of $300-350^{\circ} \mathrm{C}$, maximum decomposition process of cellulose and lignin content happened from rubber shells. The highest acid content test on liquid smoke by titrimetric was shown at the pyrolysis temperature of $350-400^{\circ} \mathrm{C}$, about $12 \%$. Identification of the chemical content of liquid smoke using GCMS was obtained with the highest content in acid products and their derivatives, with an area of acetic acid of $54.43 \%$. Liquid smoke of rubber shells formed has a $\mathrm{pH}$ of 3.4 so that it can be used as a latex coagulant and produce rubber quality of SIR 5 sheets according to SNI 1903-2011.
\end{abstract}

Keywords: Rubber Shell, Pyrolysis, Liquid Smoke, GCMS

\section{INTRODUCTION}

Rubber commodities in East Kalimantan have a significant growth area. During the 2008-2017 periods, rubber plantation's width area grew up to $3.79 \%$ on averagely, with the growth of rubber production averaged $4.88 \%$ per year. In 2017 the rubber planting area reached $115.160 \mathrm{Ha}$, with total production up to 63.510 tons approximately. (East Kalimantan's Provincial Agriculture Department, 2018). In addition to producing the rubber latexs that are their main product, Rubber trees also produce plentiful rubber shells. Due to rubber plantation growth in East Kalimantan, rubber shells' production is increasing as well so it has potentially become untapped waste.

Liquid smoke is a liquid mixture from smoke dispersion colloids in the water, which was the condensation products containing few components formed due to pyrolysis of organic material, such as cellulose, hemicellulose and lignin. During pyrolysis, cellulose will produce carbonyl and acetic acid along with its homologous, lignin will produce phenol and tar, and hemicellulose will produce furfural, furan and carboxylic acid [1]. The manufacture of liquid smoke from rubber shells with a pyrolysis temperature of $200^{\circ} \mathrm{C}$ produces liquid smoke with a $\mathrm{pH}$ of 2,495 and an acid content of $13.71 \%$ acid [2]. Various agricultural product has biomass waste contain specific chemical and physics properties that produce different liquid smoke quality. Therefore, an application is crucial to analyze the liquid smoke component in various biomass waste [3].

The liquid smoke utilization of rubber shells was hoped to replace formic acid that was usually used as coagulant latex. Formic acid is an expensive and hard to get coagulant chemical. Therefore, it was needed to 
indentify and characterize the quality of liquid smoke from the rubber shells in various temperature processes that could be used as coagulant latex to increase the value of rubber shells waste and increase environmentally friendly use material.

\section{METHODOLOGY}

\subsection{Research Material}

Rubber shells and latex obtained from CV Nursery Marang Kayu Kutai Kartanegara

\subsection{Tools}

Pyrolysis tank, oven, glassware, furnace, stove, scale, $\mathrm{pH}$ meter, measuring cups, rubber grinding tool, coagulation container, GCMS

\subsection{Method}

Rubber shells are dried up under the sun until dry (water content $\pm 10-15 \%$ ). The rubber shell is scaled before being entered into the pyrolysis tool. Next heats up the temperature $250-300^{\circ} \mathrm{C}, 300-350^{\circ} \mathrm{C}, 350-400^{\circ} \mathrm{C}$, $400-450^{\circ} \mathrm{C}$. When the pyrolysis tool is heated up, the condenser is watered with $\pm 25^{\circ} \mathrm{C}$ to cooling down the formed. During the pyrolysis process, the temperature and time are measured. The formed liquid smoke is paced into Erlenmeyer and measured its volume to know the amount of rendement production. Liquid smoke is identified by using GCMS Methods.

\section{RESULTS AND DISCUSSION}

Research results are conducted by using several steps. The following results are obtained:

\subsection{The Content of Rubber Shells}

Rubber shell as raw material from Marangkayu Kutai Kartanegara is tested, it showed in Table 1.

Table 1. Rubber Shells test

\begin{tabular}{lc}
\hline \multicolumn{1}{c}{ Parameter Uji } & Hasil Uji \\
\hline Haloselulosa & $76.7 \%$ \\
Alfa selulosa & $44.267 \%$ \\
Kadar abu & $23.25 \%$ \\
Kadar air & $10.57 \%$ \\
Karbon terikat & $0.353 \%$ \\
\hline
\end{tabular}

Rubber Shells containing high halo cellulose and alfa cellulose; $76.7 \%$ and $44.267 \%$ respectively, ash content $23.25 \%$, and water content $10.57 \%$, where rubber shells have been dried up for three days. During the process of pyrolysis, the cellulose will produce carbonyl and acetic acid with its homologous. Biomass pyrolysis produces methanol rendement from methoxyl groups such as uranic acid and methyl ester and the other decomposition of the plant material, acetic acid component, from the acetyl group on hemicellulose [4].

\subsection{Liquid Smoke Rendement}

Rendement is the parameter to estimate the amount of raw material in producing products and know the processing efficiency rate. In this research, $20 \mathrm{~kg}$ of rubber shells obtained rendement $\pm 30.6 \%$ with leftover charcoal, about $43 \%$. Meanwhile, the amount of liquid smoke rendement obtained in each temperature process could be seen in Figure 1.

\section{Liquid Smoke Volume}

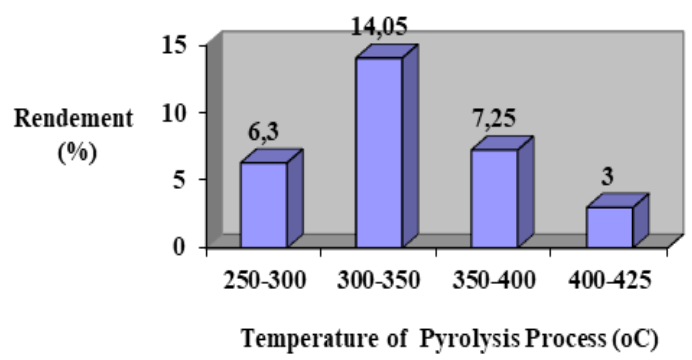

Figure 1 Liquid smoke of rubber shells' result.

Figure 1 shows the average result of liquid smoke obtained from shells pyrolysis process has yield as following results: temperature range $250-300^{\circ} \mathrm{C}$ rendement's amount: $6.3 \%$; temperature range 300 $350^{\circ} \mathrm{C}$ rendement's amount: $14.05 \%$; temperature range $350-400^{\circ} \mathrm{C}$ rendement's amount: $7.25 \%$ and temperature range $400-425^{\circ} \mathrm{C}$ rendement's amount $3 \%$. Liquid smoke of rubber shells obtained the most at pyrolisis range $300-350^{\circ} \mathrm{C}$ with rendement's amount: $14.05 \%$ amount. According to [5], the result is the condensation result of rubber shells' pyrolysis process obtained the most at temperature $300 \mathrm{oC}$ for 3 hours duration. According to [6], liquid smoke of bamboo's rendement obtaining from pyrolysis reaching $61.34 \%$, liquid smoke of pine wood $49.60 \%$ and liquid smoke of teak wood $43.78 \%$. The amount of liquid smoke rendement produced by the pyrolysis process depends on the type of the chosen raw material [7]. According to [8], the liquid smoke composition is influenced by the temperature and pyrolysis time. The yield will increase according to the increase in pyrolysis time. The more raw materials, the longer it takes for the decomposition process. However, there was a decrease in yield with increasing time. This is due to the high temperature and long time, causing a greater loss of weight. This happens because the temperature of the water in the condenser increases so that the smoke is not condensed optimally. 
The decomposition of rubber shells contents' time show in Figure 2.

\section{Time of Pyrolysis Process}

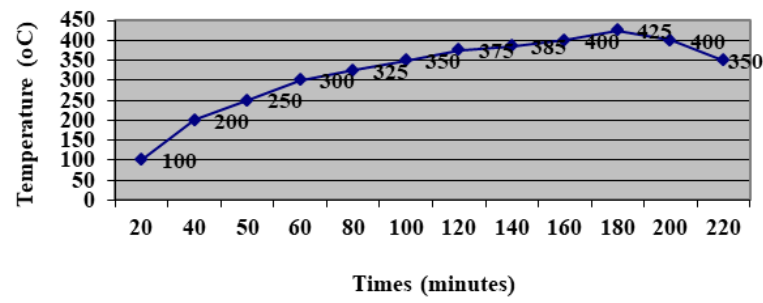

Figure 2 Time of Pyrolysis process.

Figure 2 shows that the pyrolysis process's total time is 200 minutes with shells' weight of about $20 \mathrm{~kg}$.
The longest time for the decomposition of rubber shells is 60 minutes with pyrolysis temperature at $350-400^{\circ} \mathrm{C}$. This condition shows the perfect decomposition reaction that happened from the rubber shells.

The maximum temperature is reached at $425^{\circ} \mathrm{C}$, after that it show to experience decreasing temperature and only obtain liquid smoke with lowest rendement about 3\%. This happened both due to burned out rubber shells and turned to charcoal residue

\subsection{Chemical Components Content of Rubber Shells' Liquid}

Liquid smoke is tested using GC-MS to know the content of the chemical component in it. The test result of the various temperature against component can be seen as following:

Table 2. Liquid Smoke Components in the Temperature Pyrolysis Process at 250-300oC

\begin{tabular}{ccl}
\hline No & \% area & \\
\hline 1 & 24.88 & Acetic acid (CAS) Ethylic acid \\
2 & 12.11 & Anhydro Beta D-Glucopyranose \\
3 & 8.06 & Acetic acid, propyl ester (CAS), n-Propyl acetate \\
4 & 7.89 & 2-Propanol (CAS) Isopropyl alcohol \\
5 & 5.78 & 2-Furancarboxaldehyde (CAS) Furfural \\
6 & 3.00 & Butanal, 3-methyl- (CAS) 3-Methylbutanal \\
7 & 2.92 & Phenol, 2,6-dimethoxy- (CAS) 2,6-Dimethoxyphenol \\
8 & 2.92 & 3(2H)-Pyridazinone, 4,5-dihydro-6-methyl- (CAS) 2,3,4,5-Tetrahydro-6-Methyl \\
9 & 2.73 & Phenol, 2-methoxy- (CAS) Guaiacol \\
10 & 2.83 & Propanoic acid, 2-methyl-, ethyl ester (CAS) Ethyl isobutyrate \\
\hline
\end{tabular}

Table 3. Liquid Smoke Components in the Temperature Pyrolysis Process at $300-350 \mathrm{oC}$

\begin{tabular}{lrl}
\hline No & \% area & \\
\hline 1 & 23.60 & Acetic acid (CAS) Ethylic acid \\
2 & 18.84 & L-Serine (CAS) Serine, L- \\
3 & 10.26 & Butanal, 3-hydroxy-(CAS) 3-Hydroxybutanal \\
4 & 5.30 & 2,5-Dimethoxybenzyl alcohol \\
5 & 4.88 & Phenol, 2,6-dimethoxy- (CAS) 2,6-Dimethoxyphenol \\
6 & 3.95 & 1-Propanol, 2-methyl- (CAS) \\
7 & 3.25 & 2-Furancarboxaldehyde (CAS) Furfural \\
8 & 3.22 & Cyclopentanone, 2-methyl- (CAS) 2- Methylcyclopentanone \\
9 & 3.18 & Phenol (CAS) Izal \\
\hline
\end{tabular}


Table 4. Liquid Smoke Components in the Temperature Pyrolysis Process at 350-400oC

\begin{tabular}{ccl}
\hline No & \% area & Liquid Smoke Components \\
\hline 1 & 40.31 & Acetic acid (CAS) Ethylic acid \\
2 & 7.89 & 1,6- Anhydro Beta D-Glucopyranose \\
3 & 6.63 & Carbamic acid, phenyl ester (CAS) Phenyl carbamate \\
4 & 6.69 & Acetic acid, pentyl ester (CAS) n-Amyl acetate \\
5 & 5.73 & Butane, 2-methyl- (CAS) Isopentane \\
6 & 4.63 & Acetic acid (CAS) Ethylic acid \\
7 & 2.80 & Acetic acid (CAS) Ethylic acid \\
8 & 2.81 & 2,5-Dimethylcyclopentanone \\
9 & 2.36 & Phenol, 2-methyl- (CAS) o-Cresol \\
10 & 2.18 & Phenol, 3,5-dimethyl- (CAS) 3,5-Xylenol \\
\hline
\end{tabular}

Table 5. Liquid Smoke Components in the Temperature Pyrolysis Process at 400-425oC

\begin{tabular}{ccl}
\hline No & \% area & \\
\hline 1 & 36.10 & Acetic acid (CAS) Ethylic acid \\
2 & 16.72 & Phenol (CAS) Izal \\
3 & 6.29 & Phenol, 2-methyl- (CAS) o-Cresol \\
4 & 6.32 & Ethane, 1,1,1-triethoxy- (CAS) Triethyl orthoacetate \\
5 & 4.78 & Cis-1,3-Dideuterio-1,3-cyclohexandiamine \\
6 & 3.36 & Phenol, 3,5-dimethyl- (CAS) 3,5-Xylenol \\
7 & 3.97 & Phenol, 2-methyl- (CAS) o-Cresol \\
8 & 2.96 & 2-Propenoic acid, 2-methyl-, pentyl ester (CAS) n-Amyl methacrylate \\
9 & 2.37 & Cyclopentanone, 2,5-dimethyl- (CAS) 2,5-Dimethyl cyclopentanone \\
\hline
\end{tabular}

The components of rubbers shells' liquid smoke in Table 2-5. The biggest component is acetic acid, and its derivatives at a temperature range $250-300^{\circ} \mathrm{C}$ with amount $32.94 \%$, temperature range at $300-350^{\circ} \mathrm{C}$ counted for $23.6 \%$, temperature range $350-400^{\circ} \mathrm{C}$ as many as $54.43 \%$ and temperature range at $400-425^{\circ} \mathrm{C}$ counted for $36.10 \%$. Liquid smoke of rubber shells also contains 2-Propanol, Furfural, Butanal, Propanoic acid, L-Serine, Butanal and its derivates, Carbamic acid and its derivatives, butane and its derivatives, and phenol. According to [9], liquid smoke from palm oil shells contained 27 components and empty fruit bunches of 13 components, with the highest concentration of chemical components, were acetic acid and phenol. According to [10], the process of wood chemical decomposition at pyrolysis process happens gradually as follows at temperature range $100-150^{\circ} \mathrm{C}$ the only thing that happened is the evaporation of water molecules, at temperature $200-240^{\circ} \mathrm{C}$, the decomposition of hemicellulose and cellulose become pyrolignate solution (organic acid with low boiling point such as; acetic acid, formiat, methanol, wood gas, wood gas $\left(\mathrm{CO}\right.$ dan $\left.\mathrm{CO}_{2}\right)$, and a few of ter). At temperature $240-400^{\circ} \mathrm{C}$, depolymerization and bond breaking between $\mathrm{C}-\mathrm{O}$ and $\mathrm{C}-\mathrm{C}$ occurred. In this temperature range, cellulose has been degraded. Lignin started to decompose, and producing tar, pyrolignate solution and $\mathrm{CO}$ gas decreased, while $\mathrm{CO}, \mathrm{CH}_{4}$, and $\mathrm{H}_{2}$ increased. At a temperature of more than $400^{\circ} \mathrm{C}$, forming an aromatic layer occurred, and lignin is still decomposing til at temperature $500^{\circ} \mathrm{C}$. The test result of acid content in rubber shell liquid using the titrimetric method shown in Table 6. 
Table 6. The test result of acid content in rubber shell liquid

\begin{tabular}{|c|c|c|}
\hline II & III & IV \\
\hline (Temperature & (Temperature & (Temperature \\
\hline $\left.300-350^{\circ} \mathrm{C}\right)$ & $\left.350-400^{\circ} \mathrm{C}\right)$ & $\left.400-425^{\circ} \mathrm{C}\right)$ \\
\hline $10.5 \%$ & $12 \%$ & $7.5 \%$ \\
\hline $\begin{array}{l}\text { Table } 6 \text { show the temperature of } 350-400 \mathrm{oC} \\
\text { obtained acid content of } 12 \% \text {. } \\
\text { The optimum condition acid content of liquid smoke } \\
\text { from rubberwood at a temperature of } 388.24^{\circ} \mathrm{C} \text { obtained } \\
\text { acid content of } 16.64 \% \text { [11]. Component of the } \\
\text { commercial liquid smoke fractions was quantified as }\end{array}$ & \multicolumn{2}{|c|}{$\begin{array}{l}\text { The liquid smoke pH value of rubber shell smoke's } \\
\text { acidity is 3.4, which can coagulate the latex. The rubber } \\
\text { sheet quality test is based on SNI 1903-2011. As shown } \\
\text { in Table 7, the test result of rubber sheet quality met the } \\
\text { quality requirements of SNI 1903-2011 and qualified as } \\
\text { SIR 5. }\end{array}$} \\
\hline
\end{tabular}
follows: acetic acid, carbonyls quantified as 2-butanone and phenols quantified as 2,6-dimethoxy phenol [12]. The acetic acid in liquid smoke has a high role as organic acids [13].

Table 7. The test result of rubber sheet quality

\begin{tabular}{ccc}
\hline Parameters & Results & SNI (Rubber Sheet) \\
\hline Po & 47 & SIR 5 30 \\
Pa & 33 & - \\
PRI & 70 & Min 70 \\
Dirt Content, $\%$ & 0.024 & Max 0.05 \\
Ash Content,\% & 0.41 & Max 0.5 \\
VM Content,\% & 0.55 & Max 0.8 \\
Nitrogen content,\% & 0.47 & Max 0.6 \\
Mooney viscosity & 69.4 & - \\
\hline
\end{tabular}

\section{CONCLUSION}

The highest component of rubber shells' liquid smoke is acetic acid and its derivatives. The highest liquid smoke rendement obtained pyrolysis temperature from 300 to $350^{\circ} \mathrm{C}$; meanwhile, the highest acetic acid content in liquid smoke obtained pyrolysis temperature from $350-400 \mathrm{oC}$ with a width of $54.43 \%$. Rubber shells' liquid smoke used as coagulant latex and can produce rubber sheet SIR 5 according to SNI 1903-2011.

\section{REFERENCES}

[1] J. Fatimah, I. Nugraha, Identifikasi Hasil Pirolisis Serbuk Kayu Serbuk Kayu Jati Menggunakan Principal Component Analysis, J. Ilmu Dasar, 6, 2005, pp. 41-47.

[2] A. Fadillah, H. Alfiarty, The Influence of Pyrolysis Temperature and Time to the Yield and Quality of Rubber Fruit (Hevea brasiliensis) Shell Liquid Smoke, 2015, pp. 1-7.
[3] A. Gani, A. Baihaqi, M. Faisal, Potential Development of Liquid Smoke from Oil Palm Solid Waste as Biofungicides, Int. J. Sci. Eng. (IJSE ), 7, 2014, pp. 65-69.

[4] M. F. Demirbas, M. Balat, Biomass pyrolysis for liquid fuels and chemicals: A review, J. Sci. Ind. Res.,. 66, 2007, pp. 797-804.

[5] Prasetyowati, M. Hermanto, S. Farizy, Pembuatan Asap Cair dari Cangkang Buah Karet Sebagai Koagulan Lateks, J. Tek. Kim., 20(4), 2014, pp. 14-21.

[6] M. Wijaya, E. Noor, T.T. Irawadi, G. Pari, "Perubahan Suhu Pirolisis terhadap Struktur Kimia Asap Cair dari Serbuk Gergaji Kayu Pinus," J. Ilmu dan Teknol. Has. Hutan, vol. 1, no. 2, pp. 7377, 2008.

[7] Rahmalinda, Amri, Zutiniar, Studi Komparasi Karakteristik Asap Cair Hasil Pirolisis dari Kulit Durian, Pelepah dan Tandan Kosong Sawit dengan Pemurnian secara Distilasi, J. Online Mhs. Fak. Tek. Sains Univ. Riau, 1, 2014, pp. 1-9. 
[8] F.S. Maulina, S. Putri, Pengaruh Suhu, Waktu, dan Kadar Air Bahan Baku Terhadap Pirolisis Serbuk Pelepah Kelapa Sawit, J. Tek. Kim. USU, 6(2), 2017, pp. 35-40.

[9] A.G. Haji, Komponen Kimia Asap Cair Hasil Pirolisis Limbah Padat Kelapa Sawit, J. Rekayasa Kim. dan Lingkung., 9(3), 2013, pp. 109-116.

[10] A.G. Haji, Z.Alim, B.W. Lay, S.H. Sutjahjo, G. Pari, Characterization of Liquid Smoke Pyrolyzed from Solid Organic Waste, J. Tek. Ind. Pertan., 16(3), 2007, pp. 111-118.

[11] R.A. Darmadji, H.A. Oramahi, Haryadi, Optimalisasi Produksi dan Sifat Fungsional Asap Cair Kayu Karet, Agritech Univ. Gajah mada, 20, 2000, pp. 147-155.

[12] S. Milly, P. Toledo, R. Ramakhrishnan, Determination of Minimum Inhibitory, J. Food Sci., 70(1), 2005, pp. 12-17.

[13] S.P.A. Anggraini, S. Yuniningsih, Utilization of Various Types of Agricultural Waste Became Liquid Smoke using Pyrolysis Process, Chem. Process Eng. Res., 28, 2014, pp. 60-66. 